\title{
Pengaruh Gaya Kepemimpinan, Pelatihan dan Promosi Jabatan Terhadap Kinerja Karyawan
}

\author{
(The Effect of Leadership Style, Training and Job Promotion on \\ Employee Performance)
}

Oleh:

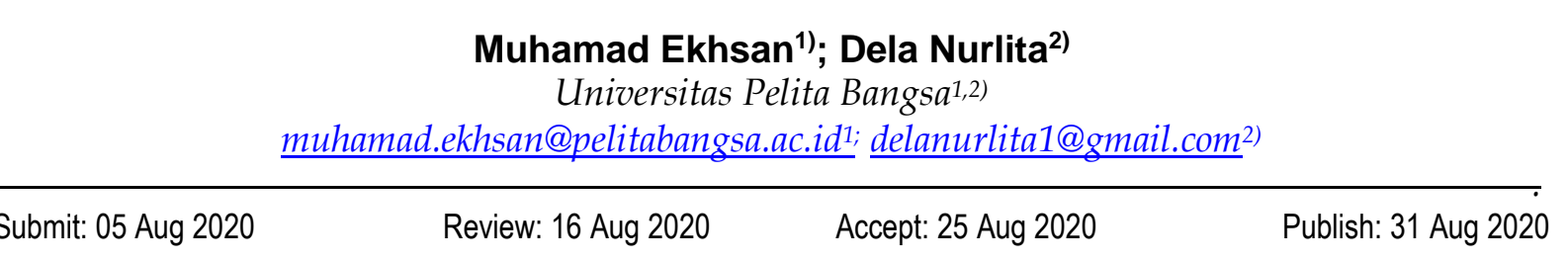

\begin{abstract}
ABSTRAK
Tujuan dari penelitian ini adalah untuk mengetahui apakah ada pengaruh gaya kepemimpinan, pelatihan dan promosi jabatan terhadap kinerja karyawan. Objek Penelitian pada PT NT Indonesia Cikarang. Penelitian dilakukan dengan menggunakan metode kuantitatif. Jumlah sampel yang diperoleh dengan teknik pengambilan sampel secara random sampling menggunakan rumus slovin berjumlah 101 responden. Pengumpulan data dilakukan melalui wawancara dan observasi. Metode analisis data yang digunakan adalah analisis regresi berganda. Hasil penelitian ini menunjukan bahwa gaya kepemimpinan, pelatihan dan promosi jabatan berpengaruh positif dan signifikan terhadap kinerja karyawan. Hal ini menunjukan bahwa apabila gaya kepemimpinan, pelatihan dan promosi jabatan meningkat maka kinerja karyawan akan meningkat secara signifikan.
\end{abstract}

Kata kunci:

Gaya Kepemimpinan, Pelatihan, Promosi Jabatan, Kinerja Karyawan

\begin{abstract}
The purpose of this study was to determine whether there is an influence of leadership style, training and promotion of position on employee performance. The object of this research is NT Indonesia Company at Cikarang. The study was conducted using quantitative methods. The number of samples obtained by random sampling technique using Slovin formula amounted to 101 respondents. Data collection is done through interviews and observations. The data analysis method used is multiple regression analysis. The results of this study indicate that leadership style, training and promotion have a positive and significant effect on employee performance. This shows that if the style of leadership, training and promotion increases the employee's performance will increase significantly.
\end{abstract}

Keywords:

Keywords: Leadership Style, Training, Job Promotion, Employee Performance 


\section{PENDAHULUAN}

Kondisi persaingan di dunia industri manufaktur saat ini terus mengalami perkembangan setiap tahunnya, sehingga menyebabkan persaingan menjadi sangat ketat baik industri lokal maupun internasional. Kondisi pasar mengalami perkembangan yang cukup pesat dibanding kondisi sebelumnya. Goodfrey (2008) menjabarkan bahwa persaingan menjadi sangat penting dalam operasi pasar, sehingga dapat mendorong inovasi, produktivitas dan pertumbuhan perusahaan. Hal ini dibuktikan dengan beberapa fenomena yang terjadi sebagai dampak dari era globalisasi yaitu munculnya pesaing-pesaing baru di dunia industri. Selain itu dampak lain yang terjadi di era globalisasi adalah perubahan selera pasar. Konsumen sekarang menuntut produk bermutu, pengiriman tepat waktu, layanan cepat, dan purna jual memuaskan. Untuk itu dibutuhkan strategi manajemen perusahaan untuk mengelola bisnis dengan ketajaman daya saing, serta terus melakukan peningkatan dan perbaikan khususnya dalam hal kinerja karyawan. Kinerja yang dihasilkan karyawan dapat menghasilkan daya saing yang lebih baik bagi perusahaan. Dalam penelitian Moran dan Brightman (2000) menyatakan kinerja yang dihasilkan karyawan menghasilkan keunggulan kompetitif bagi perusahaan sehingga dapat lebih cepat mencapai tujuan. Penelitian ini diperkuat oleh Toor dan Ofori (2009) mengemukakan kinerja yang dihasilkan digunakan sebagai penetapan standar yang tinggi bagi perusahaan.

Banyak perusahaan yang berkembang di Indonesia saat ini. Perusahaan tersebut bergerak dalam berbagai bidang. Salah satu bidang yang sedang banyak diminati di Indonesia terutama di wilayah Cikarang, Kabupaten Bekasi adalah bidang manufaktur. PT NT Indonesia adalah salah satu perusahaan yang bergerak di bidang manufaktur. Sesuai dengan bidangnya, kegiatan yang dilakukan di perusahaan ini yaitu mengoperasikan mesin, peralatan dan tenaga kerja dalam suatu proses untuk mengubah bahan-bahan mentah menjadi barang jadi yang memiliki nilai jual. Selanjutnya terkait dengan adanya fenomena yang terjadi di PT NT Indonesia, yaitu adanya penurunan kinerja karyawan terutama dari segi kuantitatif. Adapun faktor yang mempengaruhi kinerja karyawan yaitu gaya kepemimpinan. Gaya kepemimpinan para pemimpin di perusahaan tersebut cenderung bersifat otoriter, dimana segala keputusan dan kebijakan yang diambil dipusatkan secara penuh oleh pemimpin itu sendiri, atau dengan kata lain hanya diambil secara sepihak sedangkan para bawahan hanya melaksanakan tugas yang telah diberikan. Seorang pemimpin adalah orang yang diharapkan dapat memberikan pengaruh terhadap bawahannya sehingga secara langsung maupun tidak langsung dapat mendorong kinerja karyawan menjadi lebih baik lagi. Dengan kata lain, peningkatan kinerja karyawan sangat bergantung dari gaya kepemimpinan pemimpinnya. Yukl et al (2002) mengemukakan bahwa sejumlah besar penelitian empiris tentang kepemimpinan yang efektif telah berusaha untuk mengidentifikasi jenis perilaku yang meningkatkan kinerja individu dan kolektif. Sumber daya manusia dapat melaksanakan tugas yang ditugaskan, para pemimpin menggunakan gaya yang berbeda, hal ini didasarkan pada pengetahuan, nilai moral, pengalaman dan harapan sang pemimpin (Stefanovic, 2007)

Langkah selanjutnya untuk mengatasi permasalahan kinerja karyawan, perusahaan memilih beberapa strategi 
terutama dalam perencanaan sumber daya manusia. Strategi yang dipilih oleh perusahaan adalah dengan melakukan pelatihan. Tujuannya untuk meningkatkan skill dan keterampilan karyawan. Pelatihan karyawan mengacu pada program yang menyediakan pekerja dengan informasi dan keterampilan baru dalam Perusahaan yang bertujuan mendapatkan keunggulan kompetitif menyadari pentingnya pelatihan dalam meningkatkan kinerja karyawan (Zeb et al., 2018). Pelatihan yang diselenggarakan PT NT Indonesia dalam kurun waktu 3-6 bulan dan berlokasi di Perusahaan induk di Jepang ini dinilai akan mampu memicu semangat dan motivasi karyawan dalam bekerja sehingga berdampak positif terhadap peningkatan kinerja karyawan. Namun berdasarkan hasil survei dengan dengan pihak karyawan PT NT Indonesia masih ada beberapa kendala terkait pelatihan yang sudah dilakukan tersebut. Beberapa kendalanya yaitu mengenai waktu pelatihan. Umumnya pelatihan dilakukan selama 3 bulan. Namun ada juga yang mendapat pelatihan selama 6 bulan. Waktu pelatihan yang berbeda-beda ini membuat tingkat pemahaman setiap karyawan juga berbeda-beda. Selain itu, mengenai perbedaan bahasa. Hal ini dikarenakan pelatihan ini dilakukan di Jepang, sehingga bahasa sering menjadi kendala dalam berkomunikasi antara pelatih dan peserta pelatihan, apalagi peserta pelatihan sebelumnya tidak dibekali dengan pengetahuan bahasa yang cukup dan memadai.

Strategi lain yang dipilih perusahaan untuk meningkatkan kinerja karyawan yaitu melalui promosi jabatan. Promosi jabatan ini diberlakukan oleh perusahaan untuk semua karyawan, baik karyawan tetap maupun karyawan kontrak. Promosi jabatan ini dinilai perusahaan sebagai salah satu kesempatan untuk maju dan berkembang serta untuk mendorong kinerja karyawan menjadi lebih baik dan bersemangat melakukan pekerjaan di dalam organisasi atau perusahaan. Namun pada kenyataannya promosi jabatan yang dilakukan Perusahaan PT NT Indonesia belum sesuai dengan kelayakan seorang karyawan untuk dipromosikan. Promosi jabatan yang diberikan kepada karyawan dilakukan dengan melalui proses kekeluargaan, sehingga promosi jabatan yang diberikan dirasa masih kurang tepat sasaran, alhasil kinerja yang dihasilkan tidak sesuai yang diharapkan perusahaan. Navrathin (2017) mengemukakan promosi jabatan yang dilakukan manajemen perusahaan memberikan peranan penting bagi setiap karyawan, bahwa setiap karyawan menjadikan promosi jabatan menjadi tujuan yang selalu diharapkan. Hal ini sesuai dengan teori dari Kadarisman (2012) menyatakan bahwa jika karyawan dipromosikan berdasarkan asas keadilan dan objektivitas, karyawan akan memperoleh kompensasi yang lebih tinggi dan terdorong bekerja giat untuk dapat meningkatkan kinerja, sehingga sasaran perusahaan dapat dicapai.

Research gap dalam penelitian ini terkait inkonsistensi berdasarkan hasil. Riyadi (2011) menyatakan bahwa gaya kepemimpinan mempunyai pengaruh yang signifikan terhadap kinerja karyawan. Sedangkan penelitian yang dilakukan Saputra (2012), menunjukkan bahwa gaya kepemimpinan tidak berpengaruh signifikan terhadap kinerja karyawan. Secara umum, literatur yang ada menunjukan bahwa bahwa pelatihan meningkatkan kinerja organisasi dengan menciptakan angkatan kerja yang memiliki pengetahuan dan keterampilan yang luas (Tharenou et al., 2007). Selanjutnya, terdapat bukti yang terdokumentasikan 
bahwa kegiatan pelatihan memiliki pengaruh positif terhadap kinerja individu dan kinerja tim. Kegiatan pelatihan juga dapat memberikan manfaat pada hasil lainnya baik pada tingkat individu maupun pada tim (misalnya, sikap, motivasi, dan pemberdayaan) (Aguinis \& Kraiger, 2009). Penelitian Evangeline (2015) menunjukkan bahwa promosi jabatan tidak berpengaruh terhadap kinerja karyawan. Berbanding terbalik dengan Penelitian yang dilakukan oleh Mahfudz (2017) yang menunjukkan promosi jabatan berpengaruh terhadap kinerja karyawan.
METODE PENELITIAN

\section{Populasi dan Sampel}

Populasi dalam penelitian ini adalah seluruh karyawan PT NT Indonesia sebanyk 135 orang. Sampel penelitian meliputi karyawan pria maupun wanita pada PT NT Indonesia ditarik menggunakan rumus Slovin dengan tingkat kesalahan 5\% didapat 101 orang.

\section{Operasionalisasi Variabel}

Masing-masing variabel dikur dengan menggunakan indikator yang berbeda sebagaimaa dapat dilihat pada tabel 1 .

Tabel 1. Operasionalisasi Variabel

\begin{tabular}{|c|c|c|}
\hline Variabel & Indikator & Skala \\
\hline $\begin{array}{l}\text { Gaya Kepemimpinan } \\
\text { (James, 2013) }\end{array}$ & $\begin{array}{l}\text { Sikap pimpinan } \\
\text { Berani mengambil resiko } \\
\text { Delegasi wewenang } \\
\text { Kemampuan memimpin } \\
\text { Visioner } \\
\text { Kualitas materi pelatihan }\end{array}$ & Interval 1 - 5 \\
\hline Pelatihan (Tanujaya, 2015) & $\begin{array}{l}\text { Kualitas metode pelatihan } \\
\text { Kualitas instruktur pelatihan } \\
\text { Kualitas sarana dan fasilitas pelatihan } \\
\text { Kualitas peserta pelatihan }\end{array}$ & Interval $1-5$ \\
\hline $\begin{array}{l}\text { Promosi Jabatan (Navrathin, } \\
\text { 2017) }\end{array}$ & $\begin{array}{l}\text { Kejujuran } \\
\text { Kepemimpinan } \\
\text { Inisiatif dan Kreatif } \\
\text { Pendidikan } \\
\text { Kesehatan }\end{array}$ & Interval 1-5 \\
\hline $\begin{array}{l}\text { Kinerja Karyawan (Dessler, } \\
\text { 2007) }\end{array}$ & $\begin{array}{l}\text { Kualitas kerja } \\
\text { Produktivitas } \\
\text { Pengetahuan pekerjaan } \\
\text { Bisa diandalkan } \\
\text { Kehadiran } \\
\text { Kemandirian }\end{array}$ & Interval 1 - 5 \\
\hline
\end{tabular}

Sumber : Peneliti, 2020 


\section{Desain Penelitian}

Pengaruh antar variabel dalam penelitian dapat dilihat pada gambar 1 .

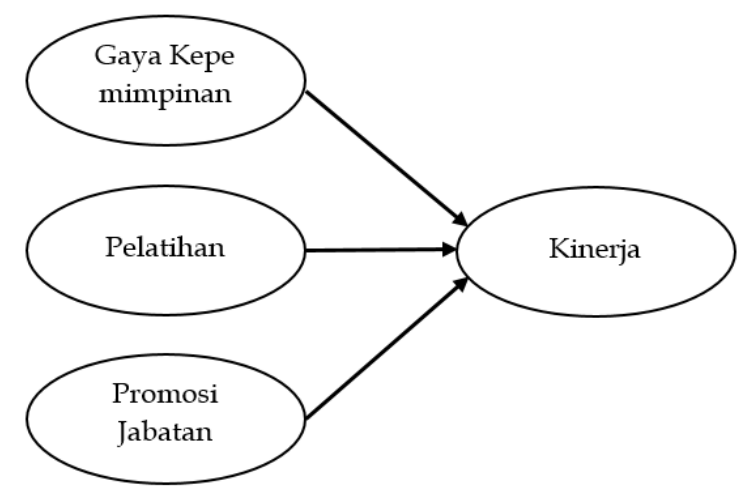

Gambar 1. Desain Penelitian

\section{Metode Analisis Data}

Pengujian data yang digunakan dalam penelitian ini meliputi uji validitas, reliabilitas, analisis regresi linear berganda, uji $t$ untuk menguji dan membuktikan hipotesis penelitian, uji $\mathrm{f}$ dan koefisien determinasi.

\section{HASIL PENELITIAN}

Uji persyaratan analisis yang digunakan adalah uji asumsi klasik yang terdiri dari uji normalitas, uji multikolinieritas dan heteroskedastisitas. Uji Normalitas dilakukan dengan P-P Plot dengan hasil bahwa titik titik menyebar sekitar garis dan mengikuti garis diagonal. Tidak ada satu pun dari variabel independen yang memiliki nilai VIF lebih dari 10,00, jadi tidak ada multikolinearitas antara variabel independen dalam model regresi. Hasil Uji Heteroskedastisitas dengan scatterplot menunjukan bahwa titik-titik berada di atas dan di bawah angka 0 pada sumbu $Y$ dan tidak berpola maka tidak terjadi Heteroskedastisitas.

Kelayakan model terlihat dari nilai koefisien determinasi sebesar 0,554 dan adjusted $R$ square sebesar 0,540 , terlihat pada tabel 2 .

Tabel 2. Hasil Analisis Koefisien Determinasi

Model Summaryb

\begin{tabular}{ccccc}
\hline Model & $\mathrm{R}$ & R Square & Adjusted R Square & $\begin{array}{c}\text { Std. Error of the } \\
\text { Estimate }\end{array}$ \\
\hline 1 & $.744^{\mathrm{a}}$ & .554 & .540 & 2.669
\end{tabular}

Sumber: Data Penelitian yang Diolah, 2020

Tabel 3. Hasil Uji F

ANOVAa

\begin{tabular}{clccccc}
\hline & Model & Sum of & & & & \\
& Squares & Df & Mean Square & F & Sig. \\
\hline \multirow{2}{*}{1} & Regression & 857.856 & 3 & 285.952 & 40.150 & $.000 \mathrm{~b}$ \\
& Residual & 690.837 & 97 & 7.122 & & \\
& Total & 1548.693 & 100 & & & \\
\hline
\end{tabular}

Sumber Data: Data Penelitian yang Diolah, 2020 
Tabel 4. Analisi Regresi Linier Berganda

\begin{tabular}{llccccc}
\hline \multirow{2}{*}{ Model } & \multicolumn{2}{c}{$\begin{array}{c}\text { Unstandardized } \\
\text { Coefficients }\end{array}$} & $\begin{array}{c}\text { Standardized } \\
\text { Coefficients }\end{array}$ & $\mathrm{t}$ & Sig. \\
\cline { 3 - 4 } & $\mathrm{B}$ & Std. Error & Beta & & \\
\hline 1 & (Constant) & 1.441 & 4.578 & & .315 & .754 \\
& Gaya Kepemimpinan & .314 & .153 & .236 & 2.054 & .043 \\
Pelatihan & .241 & .116 & .176 & 2.076 & .041 \\
Promosi Jabatan & .639 & .171 & .422 & 3.730 & .000
\end{tabular}

Sumber Data: Data Penelitian yang Diolah (2020)

Hasil perhitungan dengan menggunakan program SPSS versi 24 dapat diketahui bahwa koefiesien determinasi (Adjusted $\mathrm{R}$ square) yang diperoleh 0,540 . Hal ini berarti $54 \%$ gaya kepemimpinan, pelatihan dan promosi jabatan berpengaruh terhadap kinerja karyawan sedangkan sisanya yaitu $46 \%$ kinerja karyawan dipengarui oleh variabelvariabel lainnya yang tidak diteliti dalam penelitian ini.

Uji kelayakan model mendapat kesimpulan yang layak dimana hasil pengujian mendapatkan nilai Sig. F sebesar 0.000atau dibawah taraf uji penelitian sehingga Ho ditolak. Hasil analisis untuk mendapatkan uji F dapat dilihat di tabel 3.

Pengujian hipotesis dilakukan berdasar koefisien regresi dan nilai probabilitas sebagaimana terangkum pada table 4. Berdasarkan output SPSS, maka diperoleh persamaan regresi sebagai berikut:

$\left.Y=1,441+0,314 X_{1}+0,241 X_{2}+0,639 X_{3} \ldots . .1\right)$ Koefisien variabel gaya kepemimpinan sebesar 0,314 artinya jika gaya kepemimpinan mengalami kenaikan, maka kinerja karyawan akan mengalami kenaikan sebesar 0,314 atau 31,4\%. Koefisien bernilai positif artinya antara gaya kepemimpinan dan kinerja karyawan hubungan positif. Kenaikan gaya kepemimpinan akan mengakibatkan kenaikan pada kinerja karyawan. Koefisien variabel pelatihan sebesar 0,241 artinya jika pelatihan mengalami kenaikan, maka kinerja karyawan akan mengalami peningkatan sebesar 0,241 atau $24,1 \%$ Koefisien bernilai positif artinya antara pelatihan dan kinerja karyawan hubungan positif. Kenaikan pelatihan akan mengakibatkan kenaikan pada kinerja karyawan. Koefisien variabel promosi jabatan sebesar 0,639 artinya jika promosi jabatan mengalami kenaikan, maka kinerja karyawan akan mengalami peningkatan sebesar 0,639 atau $63,9 \%$. Koefisien bernilai positif artinya antara promosi jabatan dan kinerja karyawan hubungan positif. Kenaikan promosi jabatan akan mengakibatkan kenaikan pada kinerja karyawan.

\section{PEMBAHASAN}

Gaya kepemimpinan berpengaruh terhadap kinerja karyawan. Artinya bahwa semakin meningkat gaya kepemimpinan seorang karyawan maka akan berpengaruh terhadap peningkatan kinerja karyawan. Hasil penelitian ini relevan dengan penelitian yang dilakukan oleh Imelda Talahatu (2015) dengan dengan hasil adanya Pengaruh Gaya Kepemimpinan Terhadap Kinerja Karyawan PT Kimia Farma Trading dan Distribution Cabang Ambon. Dalam kondisi ini menggambarkan bahwa semakin baik gaya kepemimpinan di PT NT Indonesia maka akan berpengaruh terhadap peningkatan kinerja karyawan. 
Pelatihan berpengaruh terhadap kinerja karyawan dengan arah positif, sehingga dapat disimpulkan bahwa semakin meningkat pelatihan maka berpengaruh terhadap peningkatan kinerja karyawan tersebut. Hasil penelitian ini relevan dengan penelitian yang dilakukan oleh Yossy Kanta Marga (2016) dimana Pelatihan berpengaruh Terhadap Kinerja Karyawan Pada PT Pelayaran Tempuran Emas Surabaya. Dalam kondisi ini menggambarkan bahwa semakin baik pelatihan karyawan di PT NT Indonesia maka akan berpengaruh terhadap peningkatan kinerja karyawan.

Promosi jabatan berpengaruh terhadap kinerja karyawan dengan arah positif sehingga dapat disimpulkan bahwa semakin meningkat promosi jabatan maka akan berpengaruh terhadap peningkatan kinerja karyawan tersebut. Hasil penelitian ini relevan dengan penelitian yang dilakukan oleh Ela Suparinah (2018) dengan hasil bahwa Promosi Jabatan berpengaruh Terhadap Kinerja Karyawan Pada PT Waru Kaltim Plantation Di Penajam Paser Utara. Dalam kondisi ini menggambarkan bahwa semakin banyak promosi jabatan di PT NT Indonesia maka akan berpengaruh terhadap peningkatan kinerja karyawan.

\section{KESIMPULAN}

Gaya kepemimpinan berpengaruh terhadap kinerja karyawan PT NT Indonesia. Pelatihan berpengaruh terhadap kinerja karyawan PT NT Indonesia. Promosi jabatan berpengaruh terhadap kinerja karyawan PT NT Indonesia.

Gaya kepemimpinan, pelatihan serta promosi jabatan harus lebih ditingkatkan, hal ini dikarenakan mempunyai pengaruh secara signifikan, terhadap kinerja karyawan. Maka PT NT Indonesia harus tetap mempertahankan dan juga meningkatkannya dengan memperhatikan beberapa aspek indikator yang mempengaruhi gaya kepemimpinan, pelatihan serta promosi jabatan. Hal ini dilakukan dengan tujuan agar kinerja karyawan meningkat dan tujuan perusahaan tercapai dengan maksimal. Pada penelitian selanjutnya dapat dilakukan pengembangan dengan menambah variabel lain yang belum diteliti dengan pengaruh langsung maupun tidak langsung. Selain itu penelitian ini masih perlu dikembangkan dengan menambah jumlah sample serta tidak terbatas pada satu perusahaan saja.

\section{PUSTAKA}

Aguinis, H., \& Kraiger, K. (2009). Benefits of training and development for individuals and teams, organizations, and society. Annual Review of Psychology, 60, 451-474. https://doi.org/10.1146/annurev.psych.60.110707.163505

Darmanto, R. F. (2018). Pengaruh Budaya Kerja, Disiplin Kerja Dan Koordinasi Terhadap Kinerja Karyawan PT Kereta Api Indonesia (Persero) Daop 1 Jakarta. Jurnal Pengembangan Wiraswasta, 20(2), 79-94.

Dessler, G. (2007). Manajemen Personalia (Ketiga). Erlangga.

Evangeline, S., \& Thavakumar, D. (2015). The Impact of Compensation , Performance Evaluation and Promotion Practices on Employees ' Job performance - A study on Insurance Companies in Batticaloa District. 4th Annual Internatinal Research Conference, 2008, 59-67.

Godfrey, N. (2008). Why Is Competition Important for Growth and Poverty Reduction? Forum American Bar Association, 1-12.

Kadarisman, M. (2012). Manajemen Pengembangan Sumber Daya Manusia. PT Raja Grafondo Persada.

Mahfudz, R. V. (2017). ( Studi pada Badan Kepegawaian Daerah Provinsi Jawa Tengah ). 6, 1-15. 
Navrathin, Dotulong, D. S. L. O. H., \& Adolfina. (2017). Pengaruh Promosi Jabatan Dan Mutasi Terhadap Kinerja Pegawai (Studi Pada Pegawai Kantor Wilayah Direktorat Jenderal Perbendaharaan Provinsi Sulawesi Utara). Jurnal Riset Ekonomi, Manajemen, Bisnis Dan Akuntansi, 5(2), 404-413. https:// doi.org/10.35794/emba.v5i2.15686

Ofori, G., \& Toor, S. U. R. (2009). Research on cross-cultural leadership and management in construction: A review and directions for future research. Construction Management and Economics, 27(2), 119-133. https:// doi.org/10.1080/01446190802616937

Riyadi, S. (2011). Pengaruh Kompensasi Finansial, Gaya Kepemimpinan, dan Motivasi Kerja Terhadap Kinerja Karyawan pada Perusahaan Manufaktur di Jawa Timur. Jurnal Manajemen Dan Kewirausahaan, 13(1). https:// doi.org/10.9744/jmk.13.1.40-45

Stefanovic, N. (2007). ONE-DIMENSIONAL AND TWO-DIMENSIONAL LEADERSHIP STYLES. International Quality Conference.

Tharenou, P., Saks, A. M., \& Moore, C. (2007). A review and critique of research on training and organizational-level outcomes. 17, 251-273. https:// doi.org/10.1016/j.hrmr.2007.07.004

W., M. J., \& K., B. B. (2000). Leading organizational change. Journal of Workplace Learning, 12(2), 66-74. https:// doi.org/10.1108/13665620010316226

Yukl, G., Gordon, A., \& Taber, T. (2002). Taxonomy of Leadership Behavior : Half Century of Behavior Research. Journal of Leadership \& Organizational Behavior, 9(1), 15-32. https://doi.org/10.1177/107179190200900102

Zeb, A., Sultan, F., Hussain, K., Javaid, M., Abbas, Z., Imran, M., \& Pakistan Corresponding Author, M. (2018). The Influence of Compensation and Benefits and Employees' Involvement on Employees' Outcomes-Evidence from PTCL. International Journal of Research \& Review (Www.Ijrrjournal.Com),5(November), 11. www.ijrrjournal.com 